On the Longicornia of Australia, with a List of all the Described Species, \&c. By Francis P. Pascor, F.L.S., F.Z.S., \&c., late Pres. Ent. Soc.

[Read June 21, 1866.]

A IIsT of Australian Longicornia which I published about seven years ago, contained the names of 259 species. Through the kindness of many friends this number has now been brought up to nearly 500 ; but if we take into consideration the economy of these insects, their usually short lives in the perfect state, and their attachment to certain trees in which their larve have fed, confining their distribution in many cases to very narrow limits, we can scarcely avoid drawing the conclusion that we are still very far from having a complete list. However, it is I think desirable, in the dispersed condition of zoological literature, that we should now and then examine the materials that have been accumulated, and indicate where they are to be found; and this I have attempted to do in the following pages.

The boundaries of these austral lands, riewed as a zoological region solely in relation to the Coleoptera, seem to be strictly limited to Australia and Tasmania,-New Guinea, to the north, belonging to the Malay region, and very decidedly separated by Torres Straits; while New Caledonia and New Zealand, to the east, can be regarded as satellite regions only - that is, as containing a mixture of no very decidedly characteristic geographical genera with a few others strictly endemic and often of very remarkable structure.

If we take the Coleoptera as an order, then the Longicornia may be regarded as a suborder composed of the three families of Lamiida, Cerambycido, and Prionida. Each of these is divided into numerous subfamilies, from which we pass to the genera and species.

The Longicornia offer many difficulties in their classification. Many of the technical characters used for defining the genera do not amount to more than modifications, sometimes with almost insensible gradations between them; but genera, like species, are often differentiated by very slight characters only, and what is true of one is as true of the other. It is not, however, to be inferred that the genera themselves are in such cases so insensibly connected; it is the characters by which we attempt to indicate them. Occasionally, too, we find the generic characters merging into the specific; and yet the genus, in the sense of a group of 
nearly comnected species, is not thereby by any means invalidated. To meet the objections to such groups, it is sometimes proposed to call them "subgenera;" but the idea of overcoming such a difficulty by the alteration of a name seems to me to be a mere delusion. Well-defined genera require aberrant species to be eliminated; if the genera are to be enlarged to meet such cases, then the genera, as such, cease to have any definable limits, and can convey no certain idea to the mind. Having acted on the principle of the first proposition, it has appeared to me desirable to make these remarks in order to meet the objection of those who consider, not that the number of genera should be regulated by their praetical utility, but that it should be limited so as to avoid the inconvenience of taxing the memory. It is, I think, a great point gained when the knowledge of one member of a genus enables us, with the aid of a short diagnosis, to form a good idea of another; and this can only be done by a careful avoidance of mixing incongruous species together into one genus. For this, many new genera will have to be propounded; and this practice appears unquestionably to be becoming more and more the tendency of modern systematists. It may, however, be carried too far, as when nearly allied species are separated solely on technical grounds-such separatists failing to see that what may be good generic characters in one case are only of specific importance in another.

In order to make this list as complete as possible, I have prefixed descriptions of the following new species. Some of them and a few other interesting forms, not hitherto figured, are represented in the two plates appended to this Catalogue.

\section{HeBesecis SPARSA.}

$H$. nigra; antennis annulatis; scapo modice elongato; prothorace supra glabro, utrinque niveo pubescente; elytris ovatis, bicarinatis, maculis niveis pubescentibus dispersis.

Hab. Western Australia.

Black; head broad in front, with little tufts of white hairs: antennæ rather larger than the body; the scape subelongate, obconic; the third and fourth joints, at the base, and the sixth and eighth, white : prothorax glabrous above, closely punctured, the sides covered with a dense snowy-white pubescence; scutellum small, rounded posteriorly : elytra ovate, rather coarsely punctured, covered with small white tufts of pubescence, each elytron with two rather strongly marked carinæ: body beneath with a tufted whitish pubescence; legs slightly pubescent. Length 4-7 lines.

LINN. PROC.-ZOOLOGY, VOL. IX. 
This species has long stood in our collections as Hebecerus sparsus, Reiche, a name, I believe, never published. It is related to $\boldsymbol{H}$. Germari, but, inter alia, it has a longer scape, and the prothorax has not the white stripe at the side.

\section{Neissa.}

Caput antice transversum, tuberibus antenniferis brevibus. Oculi late emarginati. Antenna sparse pilosæ, corpore longiores; scapo modice

* elongato, apicem versus sensim crassiore, articulo tertio quam scapus paulo breviorè, quarto præcedenti æquali, cæteris gradatim decrescentibus. Prothorax capite vix latior, quadratus, utrinque abrupte spinosus. Elytra oblonga, basi cristata, lateraliter deflexa, apice integra. Pedes subbreves, æquales. Pro- et mesosterna simplicia.

A small species, resembling Pentacosmia scoparia in habit and colour, is the type of this genus. From Pentacosmia, however, it differs in its quadrate prothorax, basal crests of the elytra, antennæ with the third joint not longer than the scape, the fourth equal to the preceding, and the remainder gradually diminishing in length. Illcena, Er., is probably nearly allied to this genus; but he describes the prothorax as only slightly nodose at the sides. The other characters given by Erichson are very general; but he compares it to Ancesthetis and Deroplia (Stenidea). Of the second species I have seen only a single example. Both species $I$ owe to Mr. Odewahn.

\section{NEISSA INCONSPICUA.}

$N$. fusca, sparse albo pilosa ; elytris obșcure pallido variis.

Hab. South Australia (Gawler).

Brown, clothed with more or less erect whitish hairs; the elytra faintly marked with indistinct palish patches; head and prothorax closely punctured, the lateral spine of the latter very slender even at the base; scutellum triangular; elytra subseriate-punctate, obliquely depressed outside the basal crest, the side abruptly bent down, the angle there formed not prominent, towards the apex a short, slightly elevated line ; body beneath, legs, and antennæ rufous brown, sparingly pilose. Length 2 lines.

\section{Nexssa nigrina.}

N. subdepressa, nigra, pube brevi concolore et pilis dispersis albidis tecta; antennis scapo, articulis tertio et quarto longioribus.

Hab. South Australia (Gawler).

In most of its characters closely agreeing with the preceding, but in size and colour apparently very distinct; the pubescence is also shorter, and, to the naked eye, is nearly uniformly black; the scape and third and fourth joints of the antennæe are relatively longer, and the legs are 
proportionally larger; above, all the body and especially the elytra are decidedly depressed. Length $3 \frac{2}{2}$ lines.

\section{BuCYNThIA.}

Caput antice quadratum. Oculi parvi, remoti. Antenne graciles, fimbriata, basi distantes; scapo modice elongato, apice subproducto, obsolete cicatricoso ; articulo tertio multo longiore, sequentibus gradation brevioribus. Prothorax transversus, lateribus minute dentatus. Elytra subdepressa, ovata, prothorace valde latiora. Pedes mediocres, fere æquales : tarsi parvi. Prosternum simplex. Mesosternum elevatum, antice subdentatum.

The only species constituting this genus was originally referred by me to Zygocera, with some of whose members, as the genus then stood, it has a considerable resemblance in form and colour. The widely separated antennæ at the base, however, show that it should be referred to the Mesosine rather than to the Hypselomince, to which I consider Zygocera belongs. The type is Bucynthia spiloptera, Pasc. (Zygocera).

\section{SyMphyletes Devotus.}

S. subangustus, ferrugineus, pube brevi, densa, subsericea tectus; prothorace subtransverso, antice paulo constricto, ad latera irregulariter rotundato, disco tubereulis quatuor parvis instructo ; elytris subparallelis, apice subtruncatis, basi leviter tuberculato-cristatis, pone medium plaga irregulari obliqua alba; tibiis quam tarsi brevioribus.

Hab. Western Australia (Perth) (Mr. Duboulay).

Rather narrow, ferruginous, covered with a short, dense, somewhat silky, greyish pile; head rather narrow in front, median line glossy black and very distinct; prothorax subtransverse, a little narrower anteriorly, the sides irregularly rounded, the disk with two transverse tubercles, behind these two others not quite so prominent; scutellum scutiform; elytra subparallel at the sides, the base broader, with two or three black shining tubercles on each, the apex rounded, behind the shoulder, at the side, a pale patch, which is nearly connected with a broad oblique irregular band behind the middle; body beneath with a long, greyish, silky pile; legs and antennæ closely pubescent, greyish, tinged with brownish yellow. Length 9 lines.

The pubescence is more silky than is usually met with in this genus; the species is otherwise very distinct, although, from its general appearance, it may be placed with $\boldsymbol{S}$. munitus, $\boldsymbol{S}$. sodalis, S. ingestus, and others.

\section{Symphyletes Duboulayi.}

S. cylindricus, pube cinerea maculis numerosis fulvis adspersa tectus ; prothorace cylindrico ; elytris parallelis, basi haud cristatis, apice ro- 
tundatis, granulis nigris nitidis numerosis instructis, ad latera plaga oblonga nivea ornatis.

Hab. Western Australia (Perth) (Mr. Duboulay).

Cylindrical, ferruginous, covered with a close short ashy pile spotted with fulvous; head rather broad and flattish in front, the pubescence ochraceous, especially round the eye, the median line black and well marked; prothorax cylindrical, with transverse interrupted lines of fulvous; scutellum rather large, subscutiform; elytra elongate, with nearly parallel sides, the apex rounded, a few black granules at the base, and several smaller ones along the suture, but more ferruginous, a snowy oblong patch on the external margin, the rest of the elytra with numerous small fulvous spots on an ashy ground; body beneath with a long ashy pubescence; the edges of the abdominal segments and spots on the sides of the sterna fulvous; legs with a whitish pubescence, spotted and clouded with fulvous; antennæ ferruginous, slightly pubescent, spotted with white. Length 9 lines.

A very distinct species, with longer and more parallel elytra than any other that I am acquainted with, and remarkable for the uniform distribution of its colours, with the exception of the snowy patch along the side.

\section{Sympirlemes subminiatus.}

$S$. ferrugineus, rufescente varius; elytris subtrigonatis, basi spinuliferis, apice truncatis, margine exteriore apiculatis.

Hab. Western Australia (Perth) (Mr. Duboulay).

Ferruginous, with a sparse greyish pile varied with patches of rufous or reddish orange, short, closely set hairs; head orange in front, and thinly punctured, the vertex ferruginous; prothorax slightly transverse, subquadrate, the sides very slightly rounded, the disk with two small central tubercles, sparsely punctured, ferruginous in the centre, orange at the sides; scutellum transversely scutiform; elytra subtrigonate, rather finely punctured, with orange patches at the base, along the suture, and on the sides, the base with a few small triangular spines, the apex truncate, its exterior margin on each side produced into a close mucro; body beneath along the middle and the abdomen covered with long ashy hairs; the breast at the sides orange; legs ferruginous, tibia scarcely as long as their tarsi ; antennæ ferruginous, varied with a pale pile. Length 7 lines.

This very distinct species may, for the present, stand after $S$. fulvescens, Pasc.

\section{SyMPHYLETES ILTACUS.}

S. subangustus, viridi-olivaceus, plus minusve denudatus; elytris basi granuliferis, apice truncatis, ad latera niveis.

Hab. Western Australia (Champion Bay) (Mr. Duboulay).

Rather narrow, dark olive-green, shining and for the most part without 
any or with very little pubescence; head with a white pubescence, principally about the eyes, and with a few long white hairs; prothorax oblong, nearly cylindrical, rugose, with widely scattered hairs, the disk with two slight tubercles; scutellum scutiform ; elytra narrowly subtrigonate, with a few large, mostly conical, granules at the base, the apex truncate, the disk more coarsely punctured at the base, where also is a sparse greyish pile, a densely pubescent snowy patch from the shoulder, gradually lessening towards the apex ; body beneath and legs with a sparse whitish pile; fore tibiæ curved, middle and posterior rather shorter than their tarsi ; antennæ with a thin whitish pubescence, and clothed with long hairs beneath. Length 6 lines.

Also a very distinct species, which may stand after $S$. variolosus, Pasc.

\section{SyMPHYLetes SIMIUS.}

$S$. ferrugineus, nitidus, fere denudatus ; elytris subtrigonatis, basi spinuliferis, apice truncatis, ad latera antice plaga pubescenti-fulva.

Hab. Western Australia (Champion Bay) (Mr. Duboulay).

Ferruginous, shining; head rather strongly punctured in front, the median line not reaching to the mouth; prothorax nearly subquadrate, irregularly punctured, with two tubercles on the disk ; scutellum subscutiform, rounded posteriorly; elytra subtrigonate, rather closely punctured, with a few scattered concolorous granules, one or two spiniform, at the base, the apex truncate, an oblong orange patch at the side near the shoulder; body beneath with a long whitish pubescence; the breast orange at the sides; legs with a few scant whitish hairs, more numerous at the tips of the tibiæ; antennæ nearly naked, a few whitish hairs fringing the lower edge. Length 7 lines.

Near S. egenus, but with truncate elytra like $S$. derasus, without, however, the snowy stripe on the side.

\section{Srmphyletes Bathurstir.}

$S$. ferrugineus, pube tenuissima grisea tectus; prothorace oblongo, subcylindrico ; elytris subtrigonatis, modice punctatis, basi leviter granuliferis, apice truncatis, margine exteriore dense niveo pubescente.

$H a b$. South Australia (Gawler) (Mr. Bathurst).

Ferruginous, with a thin scaly greyish pubescence, and minute patches of fulvous; head with a close whitish pubescence in front, and three fulvous stripes on the vertex; prothorax oblong, nearly cylindrical, the disk with two small central tubercles; scutellum rather transverse, depressed in the middle; elytra subtrigonate, rather thinly punctured, a few concolorous granules principally at the base, the apex truncate, a white densely pubescent band along the side externally; body beneath with a long greyish (on the abdomen yellowish) pile; legs and anternæ with a greyish pile; the latter fimbriated beneath. Length 8 lines. 
Differs from $S$. derasus chiefly in pubescence; there are also a few minor differences, such as the broader head, more convex in front and much less depressed between the antennæ, the longer prothorax, \&c. A good series of specimens might show that they belong to one species.

\section{Rhytiphora Odewahis.}

R. nigra, pube opaca interrupta flavescente tecta; elytris conferte flavescente maculatis, apice truncatis ; antennis albo annulatis.

$H a b$. South Australia (Gawler).

Black; pubescence opake, pale yellowish, interrupted; head with two pubescent stripes on the occiput, a vertical stripe behind the eye, the face with irregular patches; prothorax very short, having four or five narrow bands; scutellum semicircular; elytra not granulate at the base, covered with closely set pubescent spots (often confluent) of pale yellowish, the intervals very slightly pubescent, showing the black derm beneath ; body beneath with a whitish pubescence, spotted with brown; legs closely pubescent; antennæ black, the basal half from the third to the tenth joints ashy white. Length 9 lines.

A rery distinct species, and at once differentiated by the closely set spotted pubescence on the elytra. I have dedicated it to Mr. Odewahn, from whom my example was derived.

\section{RHYTIPHORA SEMIVESTITA.}

$\boldsymbol{R}$. castanea, subtiliter pubescens; prothorace fasciis angustatis, elytris maculis indistinctis ochraceis ornatis, his postice plagis duabus glabris ; antennis griseo maculatis.

Hab. Western Australia (Perth).

Chestnut-brown; pubescence very thin, greyish, with linear bands on the prothorax and spots on the elytra ochraceous; head and basal joint of the antennæ nearly glabrous; prothorax transverse; elytra with numerous granules, extending to behind the middle, and of the same colour as the derm, posteriorly on each side a large glabrous patch; rest of the elytra with a mixture of pale greyish and small ochraceous spots; body beneath and legs reddish chestnut, nearly glabrous, except a few spots on the sides, borders of the abdominal segments, and lower part of the tibiæ and tarsi ; antennæ slightly pubescent, except at the base, spotted with greyish. Length 12 lines.

Also very distinet.

\section{Microtragus sticticus.}

$M$. cinereo pubescens, omnino nigro setulosus; prothorace rude punctato; elytris angustatis, maculis nigris elevatis dispersis.

$\mathrm{Hab}$. - -

Pubescence pale ashy, very dense and short; in other respects resem- 
bling $M$. arachne, but the prothorax less rugosely punctured, and the black spots on the elytra composed of stiff erect hairs, more decidedly raised above the surrounding pubescence. Additional specimens may probably show that this is only a variety; but the difference in colour is very marked. Length 7 lines.

\section{Athemistus Armitagei.}

$A$. brunneus, tenuiter griseo pubescens; prothorace antice angustiore, lateraliter dente minuto instructo, disco haud tuberculato ; elytris elliptico-ovatis, in medio quam prothorax latioribus.

Hab. Sydney.

Reddish brown, with a very fine greyish pubescence; head thinly punctured, a little convex in front; prothorax broader than the head, very sparsely but rather more coarsely punctured, narrowed anteriorly, rounded at the sides, and behind the middle furnished with a very small but distinct tooth; scutellum triangular, very indistinct; elytra searcely broader than the prothorax at the base, gradually increasing to the middle, then more rapidly rounded to the apex, the disk with very closely arranged rows of small tubercles, which towards the apex are replaced by large deeply impressed punctures, the apex of each elytron rounded; antennæ, body beneath, and legs brown, thinly pubescent; tibix with yellowish hairs at the tip; antennæ rather more than half the length of the body. Length 3 i lines.

Smaller and stouter than A. rugosulus, Guér., and well distinguished by the characters of the prothorax, elytra, \&e. I bave named it after Edward Armitage, Esq., A.R.A., who kindly presented me this and the following species, although uniques in his collection.

\section{Athemistus funereus.}

$A$. ater, obsolete pubescens; prothorace antice paulo angustiore, lateraliter dente minuto instructo; elytris oblongo-ovatis, quam prothorax vix latioribus.

Hah. Sydney.

Black, with only very faint traces of pubescence; head finely punctured; prothorax broader than the head, coarsely and rather closely punctured, somewhat narrower anteriorly, rounded at the sides, with a very small but distinct tooth; scutellum very small and indistinct; elytra oblong-ovate, scarcely broader than the prothorax in any part, slightly rounded at the sides, the apex of each rounded, the disk with very closely arranged rows of small tubercles; antennæ, body beneath, and legs reddish brown; the tips of the tibir with yellowish hairs; antennx about two-thirds the length of the body. Length $3 \frac{1}{2}$ lines.

Distinguished from the last by its larger and more coarsely punctured prothorax, narrower and more parallel elytra, and its black colour, with an almost obsolete pubescence. 


\section{Hathutodes.}

Mycerino affinis sed differt præcipue prosterno simplici, haud antice producto.

In Mycerinus dorcadioides, Serv., the prosternum is raised, produced, and transversely expanded in front, and, the propectus being reduced to a mere line, the head, or rather the under surface of the oral organs, rests against it. To this genus, which originally received the name of Hathlia from Dejean, but which was first described by M. J. Thomson*, several species have been referred by Hope, Blanchard, Guérin, and myself; they all differ, however, in the very important structural character mentioned above, and they also differ considerably among themselves. With the exception of one species, which will be referred to presently, I propose, notwithstanding, to retain all the Australian species in this genus. Nevertheless it might have been thought desirable to distinguish between those species with a fusiform outline, like Hathliodes grammicus, and those with the humeral angles of the elytra projecting beyond the base of the prothorax, like $H$. quadrimaculatus; but then this character not only varies in degree in the species, but it also varies to a certain extent in individuals, as in $H$. aridus. M. J. Thomson formed his genus Mycerinopsis on the latter, chiefly on account of its longer antennæ; but its affinity to $H$. quadrilineatus $\dagger$, Hope, is, I think, too close to allow of its separation. $H$. lineellus is a somewhat degraded form of the genus; while Hathlia gracilis and $H$. procera, the latter a Ceylon species, are altogether aberrant $¥$. The following species, which

* This is not quite correct, M. Guérin-Méneville having pointed out in his 'Iconographie' (p. 428), but in an irregular sort of way, the characters which distinguish Hathlia (or Hatlia, as it was there spelt) from Apomecyna, to which it had been united by Serville.

† This is a variable species, black to greyish ochreous, with pale or whitish lines, some of which are occasionally obsolete.

$\ddagger$ Hathlia Buckleyi, Pase. (Trans. Ent. Soc. ser. 2. iv. p. 107), I propose to separate from all the above; its genus I may briefly characterize here:-

\section{MARMYLARIs.}

Caput magnum. Antenne corpore paulo longiores, articulo quarto tertio fere xquali, cæateris brevioribus. Prothorax capite haud latior, transversus, cylindricus. Elytra valde convexa, parallela, prothorace vix latiora. Pedes validi. Pro- et mesosterna ut in Lychrosi.

A narrower and more convex form than any of the preceding, with larger head, \&c. M. Buckleyi is a peculiar species, white, the elytra covered with numerous very distinct black spots; it is from India. M. J. Thomson's Mycerinus vari. pennis appears to be referable to this species. 
has not been described hitherto, is allied to H. grammicus; both are in the collection of the British Museum, and were received from an officer of a surveying-ship, but without any precise locality; they are supposed to be from the north or north-west coast.

\section{Hathlodes moratus.}

$H$. supra pallide griseo pubescens, lateribus albidis ; elytris basi prothorace vix latioribus, oblique striatis, postice dehiscentibus, apice singulorum angulato.

Hab. North coast?

Densely pubescent, pale greyish above, whiter at the sides, irregularly punctured; head nearly as broad as the prothorax; the latter rather longer than broad; the elytra at the base scarcely broader than the prothorax, obliquely striated, dehiscent posteriorly, each apex ending in a somewhat acute angle; body beneath, legs, and antennæ covered with a dense whitish pubescence. Length $6 \frac{1}{2}$ lines.

\section{LTChROSIS.}

Caput antice paulo rotundatum. Oculi parvi. Antennce basi remotæ, corpore breviores, scapo subelongato, cylindrico, articulo tertio multo longiore, quarto præcedente breviore, sequentibus multo brevioribus. Mandibulre validæ. Prothorax lateribus rotundatus. Elytra convexa, subcylindrica. Pedes æquales. Coxa anticæ magnæ, eductx. Prosternum haud productum, antice angustius.

The type of this genus (Mycerinus luctuosus) appears to me to be so distinct in habit as to make it desirable to separate it from the other species, notwithstanding the differences which prevail among them. The most obvious peculiarities of the genus are the rounded sides of the prothorax, contracted therefore at the base, the more convex elytra, and the larger anterior coxæ. These characters might have been made more trenchant, but that I have left them sufficiently open in order to include Hathlia zebrina, Pasc., an Indian species which it is scarcely desirable to separate generically at present.

\section{Praonetha pleuricausta.}

$P$. fusca, rude pubescens; prothorace subquadrato ; elytris breviusculis, carinulatis, postice abrupte declivibus, basi piloso cristatis, apice truncatis, lateribus obseure fusco plagiatis; antennis concoloribus.

Hab. Port Albany (north coast).

Covered with a rough pale-brownish pubescence; head impunctate; prothorax subquadrate, scarcely broader than the head, the sides almost parallel ; elytra compressed, rather short, abruptly declivous posteriorly, the apex truncate, each elytron with three or four elevated 
lines on each side, the innermost with three slightly pilose crests ; at the base, middle, and apex, and towards the outer margin a large dull brownish patch; body beneath and legs brown, partially pubescent; antennæ shorter than the body, brownish. Length $4 \frac{1}{2}$ lines.

This is the second Australian species of a large genus which abounds in the Malay archipelago and is found as far north as Japan. It should be placed near $P$.propinqua and $P$. iliaca from Borneo.

\section{Sybra Centurio.}

$S$. fusca, nitida, lateribus griseo pubescentibus; elytris subelongatis, singulis biseriatim griseo guttulatis, apicibus productis, anguste acutis, dehiscentibus.

Hab. New South Wales.

Dark brown, shining; the sides more or less densely covered with a greyish pubescence, which takes the form of stripes above and below the eye and on the prothorax, but which are less definite on the elytra, and are accompanied by two rows of small greyish spots, the outer extending from the shoulder nearly to the apex, the inner row, between the suture and stripe, composed of about five or six distinct spots; head loosely pubescent in front; middle of the disk of the prothorax nearly glabrous, sparingly punctured; scutellum semicircular; elytra very slightly pubescent, except at the sides, the punctures subseriately arranged and confined to the basal half; body beneath brown, shining, speckled with a greyish pubescence; legs and antennæ brown, slightly pubescent, the latter ringed with ashy. Length 6 lines.

This well-marked species belongs to the second of the artificial sections proposed by me in 'Long. Malay.' ( $p .214$ ), into which a part of the extensive genus Sybra was located. The only other Australian species of this section ( $S$. acuta) is less related to the above than some of the Malayan species-S. pulverea for example.

\section{Essisus.}

Caput haud elongatum; fronte quadrata, convexa, infera, subhorizontali, apice producto; tuberibus antenniferis validis, subparallelis. Oculi haud divisi, mediocres. Palpi maxillares acuti. Antenna 11articulatæ, fimbriatæ, corpore paulo longiores $(\delta)$, vel breviores $(q)$; scapo cylindrico, modice elongato, piloso; articulo secundo breviter obconico ; tertio scapo longiore; quarto tertio æquali, apice infra plumoso ; articulis sequentibus multo brevioribus. Prothorax cylindricus, capite haud latior. Elytra breviuscula, angustata, parallela, apicibus rotundatis. Pedes brevissimi, æquales ; femora incrassata ; tarsi art. penultimo profunde diviso, ultimo mediocri. Pro- et mesosterna simplicia.

The subfamily Hippopsince, to which this genus belongs, has 
not been hitherto represented in Australia, although at least two genera occur in New Guinea, and others in the Malay region, as well as in Africa and America. The present genus, however, has very little affinity to either of these, but in habit more nearly resembles Pentacosmia, which is also Australian, although belonging to quite a different group. Of the two specimens before me, one (a male) is very much smaller, with longer antennæ, and the last seven joints, when taken together, quite as long as the preceding four; while in the female the first four are half as long again as the seven following. The species appears to vary as to depth of colour and amount of greyish marking.

\section{EAstsus dispar.}

$E$. brunneus, griseo varius, plumis antennarum nigris.

$H a b$. Queensland.

Reddish brown; the head and prothorax darker, sparingly pilose, and coarsely punctured above; sides of the prothorax and sides and posterior part of the elytra covered with a greyish pubescence; antenna reddish brown, the plume on the fourth joint dark brown or black; body beneath brownish, with a sparse grey pubescence. Length $2-3 \frac{1}{2}$ lines.

\section{Aqapete Vestita.}

$A$. nigrescens; capite prothoraceque, macula magna laterali excepta, rufo-fulvis, crebre et subtiliter punctulatis.

Hab. South Australia (Gawler).

Head and prothorax of equal breadth, reddish fulvous, except a large black spot on the side of the latter, minutely and finely punctured, slightly pubescent, and having also a few short erect black hairs; scutellum dark brown; elytra obscure greyish, extending to the end of the first abdominal segment; sterna and abdomen black, the sides of the former with a coarse whitish pubescence; legs black; antennæx brownish. Length 6 lines.

This species has longer elytra than either $A$. carissima or Krueslerce; from the former, with which it agrees most in colour, it is distinguished by the narrower outline of the prothorax nearly parallel at the sides, and its (and the head's) minute and closely set puncturation.

\section{EARINIs Krdeslere.}

E. nigra ; capite, frontee xcepta, prothoraceque hoc flavis, basi punctato; elytris circa scutellum, et fasciis duabus, una ante medium interrupta, flavis; antennis concoloribus.

Hab. South Australia (Gawler).

Black, with scattered erect hairs; head yellow, space between the eyes black; prothorax yellow, the anterior border not raised as in E. $m i$ - 
mula, the base punctured, as well as the disk; scutellum small, black; elytra black, the apices more pointed than in E. mimula, space round the scutellum, band before the middle, but interrupted at the suture, and another band between the middle and apex, yellow; body beneath, except the sterna, dull yellowish, the abdomen darker; legs black; antennæe entirely black. Length 5 lines.

I have great pleasure in dedicating this beautiful little Longicorn to Mrs. Kruesler, of Gawler, to whom I have been indebted for so many interesting novelties.

\section{Aposites pubicolisis.}

A. rufo-brunneus ; prothorace pone apicem constricto, lateribus et basi griseo pubescentibus ; elytris confertim punctatis.

Hab. Western Australia.

Head and prothorax pitchy brown, covered, except on the disk of the latter, with a coarse whitish or greyish pubescence ; elytra nearly glabrous, reddish brown, each with four raised longitudinal lines, the intervals closely and rather finely punctured; the apex spinose at the suture; body beneath with a close grey pubescence; legs dark reddish brown; the tarsi paler; antennæe pale reddish brown, about a third longer than the body, the third and fourth joints not dilated; prothorax broadly constricted behind the apex, the middle part swelling out into an obtuse prominence; anterior coxa strongly exserted, their acetabula broadly angulated externally. Length 13 lines.

In this species the anterior coxø are quite conical, and the angles of their acetabula considerably larger than in $A$. macilentus ; the prothorax is also constricted anteriorly, and the abdomen does not extend beyond the elytra. In these respects, and in the cylindrical third and fourth antennary joints, this species rather recedes from the type; the latter character, however, may be only sexual. The habit of the two species is almost identical. In the British Museum.

\section{URACANTHUS STMULANS.}

$U$. griseo pubescens, plaga triangulari fusca nitida pone humeros, apice elytrorum singulorum extus rotundato, dein tenuiter sinuato, sutura in spinam exeunte.

Hab. South Australia.

Entirely covered with a uniform greyish pubescence, except a triangular glossy brown patch behind the shoulder, but the patch smaller and not bordered with a densely pubescent line as in $U$. triangularis: elytra shorter than in that species, and with their apices pubescent; prothorax slightly angulated on each side in the middle; body beneath and legs closely pubescent; antennæ with a finer pubescence. Length 10-11 lines. 
It will be seen from the diagnosis that the form of the apices of the elytra is very different from that of $U$. triangularis, to which it bears a close resemblance.

\section{URACANTHUS Miniatus.}

$U$. supra ferrugineus, pube miniata tectus ; abdomine, antennis pedibusque nigris; apicibus elytrorum rotundatis.

$H a b$. Western Australia.

Ferruginous above, covered with a coarse yellowish-red pubescence; abdomen, legs, and antennæ black, with a very slight pale-greyish pubescence; sterna reddish; head slightly punctured; clypeus strongly marked; posterior half of the prothorax much broader than the anterior, elytra a little incurved at the sides, the apices rounded; eyes smaller than in other species of the genus, and considerably less approximate beneath; antennæ not reaching to the end of the elytra; mandibles and palpi brownish, the former irregularly punctured. Length 8 lines.

A slightly aberrant form of the genus, owing to its colour and smaller eyes. The specimen in the British Museum, the only one I have seen, is probably a female.

\section{OMOphona temiata.}

$O$. nigra, confertim punctata; elytris singulis lineis duabus subelevatis et vitta aurantiaca ornatis ; antennis nigris, articulis $4^{\text {to }}, 5^{\text {to }}$, et $6^{\text {to }}$ dimidio basali, albis.

\section{$\mathrm{Hab}$.}

Black, slightly nitid, with numerous slender erect hairs on the upper parts and legs; a bright orange stripe running from the shoulder to the apex; head and prothorax closely punctured, the latter broader than the head, narrower at the base, the sides somewhat parallel, the disk with three alinost obsolete tubercles; elytra scarcely broader than the prothorax, the sides parallel, two indistinct elevated lines on each ; body beneath black, the abdomen brownish, shining; legs and antennæ black, the fourth, fifth, and sixth joints of the latter with their basal halves white. Length 4 lines.

Omophoena is distinguished from its allies by its 10 -jointed antennæ. The type ( $O$. Kruesler $a)$ differs from the present more particularly in the form of its prothorax, which is narrower, and more rounded at the sides, and in the absence of any raised lines on the elytra. In the British Museum.

\section{Sidis.}

Caput triangulare. Oculi magni, reniformes, supra distantes. Antenna breves, basi remota, scapo basin versus attenuato et curvato, articulo 
tertio breviore, cæteris cum tertio æqualibus. Palpi breves, triangulares. Prothorax elongatus, medio lateraliter nodoso-rotundatus. Elytra depressa, elongata, parallela. Coxe anticæ globosæ. Pedes breves; femora incrassata; tibice sublineares; tarsi attenuati, breves. Corpus breviter setosum.

Differs from the above and other nearly allied genera in its shorter antennæ, the basal joint of which is, notwithstanding, longer than any of the others, and its shorter legs. The species described below has its whole upper surface clothed with minute setaceous hairs. In colour and general appearance it bears a - certain resemblance to Opilus mollis.

\section{SIDIS OPILOIDES.}

$S$. testacea ; capite prothorace rufo-brunneis ; elytris pone medium castaneis.

$H a b$. South Australia ( $M r$. Odewahn).

Testaceous, covered above with short setaceous hairs; head and prothorax reddish, very coarsely and closely punctured; scutellum rather large, ovato-triangular; elytra, especially at the base, covered with large deep punctures, on the posterior third, which is of a chestnutbrown colour, they are much smaller and shallower, and less crowded, the anterior testaceous portion is also in its middle a little clouded with chestnut; body beneath testaceous; the abdomen inclining to brown; legs also testaceous, the tibiæ and tarsi darker; antenna reddish testaceous, a little more than half the length of the body. Length 3 lines.

\section{Acrrusa.}

Caput antice breviter triangulare, pone oculos vix constrictum. Oculi magni, reniformes, supra distantes. Antenne sublineares; scapo brevi, basi curvato et attenuato ; articulo tertio longiore, apice spinoso ; sequentibus brevioribus et æqualibus. Palpi breves, obtusi. Prothorax elongatus, inæqualis, medio lateraliter nodosus. Elytra depressa, parallela, apice rotundata. Coxce anticx globosx. Femora elongatoclavata; tibice graciles; tarsi attenuati, breves, postici longiores. Corpus setosum.

The type of this genus, Obrium eiliatum, was described by me in the 'Ent. Trans.' ser. 3. vol. i. p. 559; at the same time I expressed an opinion that this and other species also referred to that genus, would have eventually to be separated. But the question occurs, What is the importance to be attached to the spine at the apex of the third antennary joint? Like all the other characters of the Longicornia, it is, as it appears to me to be, a question of experience, to be answered according to the weight we attach to 
other characters, which will or ought to decide the general affinities of the species in question. If we leave Acyrusa in the neighbourhood of Obrium*, how is Phoracantha (some of the species of which approach it very nearly in their characters) to be distinguished?

\section{IgENIA.}

Characteres ut in Obrio, sed coxa anticx globosæ, haud eductæ.

Proposed for the reception of Obrium ibidionoides, Pasc. (Trans. Ent. Soc. ser. 2. v. p. 26). To this I would add Obrium dorsale, Pasc. (Journ. of Entom. ii. p. 237). Between the two, but more intimately allied to the latter, is the following new species (it may be thought that the radical difference in the anterior coxæ shows that this genus has nothing whatever to do with Obrium) :-

\section{IGENIA STIGMOSA.}

1. luteo-testacea; capite, fascia lata postica et lineis duabus ante medium elytrorum castaneis.

Hab. South Australia (Mr, Odewahn).

Yellowish testaceous : the head, a broad band near the apex of the elytra, and an oblong dash on each side between the band and the base, brownish chestnut; head coarsely punctured in front, and forming between the eyes longitudinal ridges; prothorax about half as long again as broad, nodose at the sides, irregularly punctured, the punctures leaving about five smooth spaces on the disk; scutellum triangular; elytra rather narrow, subseriate-punctate, the punctures coarse, but becoming gradually less so posteriorly, behind the middle a broad chestnut band, not touching the apex; body beneath luteous, shining; band between the eyes (beneath) and last four abdominal segments chestnut; legs luteous, the tips of the tibiæ and tarsi darker; an. tenne dusky luteous, the third joint longer than either the scape or the fourth joint + . Length $4 \frac{1}{2}$ lines.

\section{Stsyritur.}

Caput antice breve. Oculi magni, reniformes, supra modice distantes. Antenne longitudine corpori æquales; articulo tertio guam scapus longiore, mutico; articulis ultimis vix compressis. Prothorax oblongus, capite latior, lateraliter irregularis. Elytra parallela, apice rotundata. Pedes mediocres, postici longiores; tarsi breves; acetabula antica cicatricosa, vix angulata.

* Obriam now contains only the three European species cantharinum, I. brunneum, Fab., and bicolor, Kraatz, the North-American O. maculatum, and probably a few others from the United States.

+ In I. ibidionoides it is longer than the fourth, but shorter than the scape; in $I$. dorsalis it is a trifle shorter than either. 
This genus scarcely differs from the former; and, on the other hand, it is not to be distinguished from some of the smaller aberrant species of Phoracantha, except for the absence of the spine on the third joint of the antennæ, and the more cylindrical form of their terminal joints. The type is Sisyrium tripartitum, Pasc. (Obrium) (Journ. of Entom. ii. p. 238).

\section{Phalota ooliaris.}

$P$. fusca, subnitida, disperse pubescens, capite nigro; prothorace luteo. Hab. South Australia (Mr. Odewahn).

Dark brown, approaching to black, with a very scanty pubescence composed of small whitish erect hairs; head black; prothorax and breast yellow; scutellum black, subscutiform, rounded behind; elytra depressed, twice as broad as the prothorax at the base, thickly punctured, the apex of each rounded; body beneath (except the breast), legs, and antennæ glossy brown. Length 3 lines.

A broader insect than Phalota tenella, and at once distinguished by its black head. The characters of the genus in the above work were drawn up from a female, but the figure given was from a male. In the latter it will be seen that the fifth and succeeding antennary joints are much longer than the third and fourth; and therefore the term subequal, applied to them, requires modification. $\boldsymbol{P}$. collaris is described from a female; doubtless the male will be found to have also longer antennæ.

\section{Xrstana.}

Caput pone oculos constrictum et elongatum ; fronte subverticali, turgida; mandibulis parvis. Oculi remote divisi, parte superiore supra distantes. Antenne remotæ, lineares, setuliferæ, articulo basali subelongato, curvato, apicem versus sensim incrassato, tertio et quarto brevioribus, cæteris paulo longioribus et subæqualibus, vel parum decrescentibus. Palpi modice elongati, articulo ultimo obconico. Prothorax antice et postice constrictus, medio lateraliter nodosus. Elytra elongata, depressa, parallela. Pedes breves; femora modice incrassata; tarsi graciles, articulo basali elongato; coxa anticæ elongatæ, contigure; acetabula antica valde extus angulata. Mesosternum depressum.

Allied to Phalota, especially in the remarkable character of the head (longer and more constricted, however, behind the eyes), in the different form of the prothorax, in the lengthened basal joint of the tarsi, and in the largely angular anterior acetabula. With regard to the latter eharacter, $I$ am afraid too much stress has been laid on it. M. J. Thomson, in his 'Systema,' divides his 
"Cerambycitce" into two subtribes-those with the anterior acetabula rounded, and those with them angulated externally; but, in fact, it is little more than a question of degree ; and his "groupe" (not "cohorte" or "sous-tribu") "Cerambycitce verce," belonging to his second subtribe, has them only slightly (paulo) angulated externally, in which case it is not to be distinguished, so far as this character is concerned, from those in his first subtribe " Catlichromite," in which it varies from a closed slit or cicatrix slightly open at its commencement and therefore forming a little angle, to the whole side of the acetabulum prolonged into a large angle, as in Tragocerus and other genera. In fact, M. Léon Fairmaire, notwithstanding the numerous divisions which he has formed for the European Longicorns, only places Callichroma and Cerambyx in the same "groupe," while in M. Thomson's 'Systema' they represent respectively the two great subtribes mentioned above.

\section{Xistema vittata.}

$X$. fusco-testacea ; elytris albescentibus, sutura et linea longitudinali exceptis.

Hab. Queensland.

Brownish-testaceous, sparsely clothed with pale, delicate, erect hairs; head finely and closely punctured, a deeply impressed line in front; prothorax also finely punctured, longer than broad, its disk with two

- oblong, slightly nitid gibbosities; scutellum subquadrate; elytra very pale yellowish white, shining as if varnished, minutely and irregularly punctured, the suture and stripe on each elytron (neither quite extending to the apex) brownish testaceous; body beneath and legs glossy luteous brown. Length 4 lines.

\section{BetheleiUM.}

Caput antice brevissimum, tuberibus antenniferis fere obsoletis. Oculi lunulati, mediocres, grosse granulati. Antenne corpori æquales vel longiores, lineares, basi distantes, scapo obconico, articulo tertio æquali, quarto abbreviato, sequentibus quam præcedentes longioribus. Prothorax oblongus, basi angustior, ad latera rotundatus, disco æquali. Elytra parallela. Coxa anticæ globosæ. Acetabula antica breviter angulata. Pedes mediocres; femora clavata. Pro- et mesosterna elevata. Corpus depressum.

The type of this genus was originally described by Mr. Newman without any generic name, and with the specific one of "signiferum;" at the same time he indicated it as being a "G. n. Callidio affine." In the same genus he also placed "__ piceum," which, however, was an old Fabrician species, and is now known as the Callidiopsis scutellaris. Bethelium is distinguished from the 
greater part of the genera of this subfamily by the form of the prothorax. My Callidium inseriptum belongs also to Bethelium.

Callidiopsis, long ago proposed to be separated from Phoracantha, has been recently described by M. J. Thomson, who has also adopted Callirhoë, though under another name; and thus it becomes necessary to examine what remains. Phoracantha as a genus was never in a very satisfactory state. Mr. Newman characterized it in a most general way (it was difficult, indeed, to do otherwise), but giving as a reason that " descriptionem fusiorem haud requirat genus percognitum." It included several series of forms, each of which, taken as a group of species, could scarcely be distinguished by characters without admitting certain exceptions, or by using others which further observations might prove to be only of specific importance; and hence Phoracantha has stood, like many other genera, a collection of many discrepant species. With the materials I have before me, I have proposed the following genera, which I think will be found to include only obviously related species, and no others. They are taken in an ascending scale, Phorocantha standing nearly in the middle. The characters of Phoracantha, as here limited, are as follows :-

\section{Phoracantha.}

Caput pone oculos haud elongatum; frons brevis, apice lata. Labrum transversum. Antennce elongatæe ( $q$ multo breviores), articulis sủbteretibus, $3^{\mathrm{io}}-6^{\mathrm{tum}}$ apice spinosis. Prothorax latus, longitudine latitudini fere æquali, lateribus spinosis. Elytra oblonga, apicibus bispinosis. Femora in medio vix incrassata; tibice anticæ rectæ. Corpus plerumque robustum.

The type is Phoracantha semipunetata, Fab. (Stenochorus).

\section{Epithora.}

Caput pone oculos elongatum ; frons brevis, apice angustata. Labrum parvum. Antenne corpore duplo longiores, articulis cylindricis, $3^{\text {io }}$ $7^{\text {xam }}$ apice spina valida instructis. Prothorax oblongus, lateribus inæqualis. Elytra elongata, apicibus bispinosis. Femora in medio incrassata ; tibia anticæ curvatæ. Corpus elongatum.

The type is Epithora dorsalis, MacLeay (Stenochorus). This genus is peculiarly distinguished by the greater length of the head, and the curved anterior tibiæ.

Mr. Newman has done little more than suggest the name of Callirhoe for the following, in the event of its being " raised to generic honours." Mr. Hope includes it in his genus Coptocercus.

\section{Callirhot:}

Frons subbrevis, apicề angustata. Labrum parrum. Antenna articulis 
$3^{\text {io }-6}$ vel $7^{\text {mum }}$ apice spinosis. Prothorax elongatus, lateribus tuberculatus (ex. aberrans et polita). Elytra modice elongata, apicibus univel bispinosis (ex. pubescens). Femora valde clavata, basi elongata. Corpus angustatum.

The type is Callirhoë biguttata, Don. (Stenochorus). The long, strongly clavate femora, and narrow body, will in general at once distinguish this genus. These characters hold good for all the species except $C$. aberrans, which has only moderately clavate femora.

Atesta.

Frons brevis, apice angustata. Labrum minutum. Antenna mediocres, articulo tertio apice valde spinoso, quarto obsolete spinoso, exeteris inermibus. Prothorax elongatus, lateribus tuberculatus. Elytra parallela, apice rotundata. Femora in medio incrassata. Corpus modice elongatum.

The type is Atesta balteata, Pasc. (Phoracantha). The only genus with the apex of the combined elytra rounded; A. Angasii, is so far exceptional that a rery short mucro may be seen with the aid of a lens at the sutural angle.

\section{Allotists.}

Frons brevis, apice lata. Labrum breve, transversum. Antenne setaceæ, articulis tertio et quarto apice subspinosis. Prothorax elongatus, lateribus tuberculatus. Elytra parallela, apicibus truncatis, haud spinosis. Femora clavata, basi elongata. Corpus gracile.

The type is Allotisis scitula, Pasc. (Phoracantha). The spines on the antennæ are reduced to a minimum in this genus, while the truncated apices of the elytra mark the first approach to spines, which we find throughout the remainder.

\section{Drospides.}

Frons subbreve apice subangustata. Labrum transversum. Antennce articulis depressis, $3^{\text {io }}-8^{\text {rum }}$ apice valde spinosis. Prothorax longitudine haud latior, lateraliter spinosus. Elytra oblonga, apicibus bispinosis. Femora sublinearia, tibice et tarsi graciles. Corpus robustum.

The only species is Diospides obscurus, Don. (Stenochorus). It is principally distinguished from Phoracantha by its linear or nearly linear femora.

\section{Tryphocharta.}

Frons paulo producta, apice angustata. Labrum transversum. Antennce corpore vix longiores (in foem. breviores), articulis $3^{\text {io }}-8^{\text {vum }}$ apice bispinosis. Prothorax parvus, lateraliter spinosus. Elytra ampliata, apicibus bispinosis (ex. Odewahnii). Femora linearia. Corpus peramplum.

The type is Phoracantha hamata, Newm. The genus is remarkable for its small prothorax and its large elytra. 


\section{XYPETA.}

Frons brevissima, apice dilatata. Labrum mediocre. Antenne corpore longiores, 11 -articulatæ, articulis plus minusve depressis, $3^{\text {to }}-6^{\text {tum }}$ apice bispinosis, art. ultimo inciso, articulum duodecimum simulante. Prothorax subtransversus, lateraliter dentatus. Elytra oblonga, apicibus bispinosis. Pedes antici breves, postici longissimi ; femora linearia, postica extremitatem corporis superantia. Corpus robustum.

The only species has been recently described by me under the name of Phoracantha grallaria, and is one of the most remarkable of the whole subfamily, owing to its very short anterior legs, and the unusual length and slenderness of the remainder.

\section{Didymocantha BRevicolis.}

D. fusca, sparse pilosa, aliter fere glabra; prothorace transverso ; scutello fusco; elytris testaceis, nitidis, vage punctatis, plaga obliqua humerali et apice fuscis ; antennis fœminarum corpore brevioribus.

Hab. Western Australia (Perth).

Dark brown, nearly free from pubescence, except on the antennæ, but with numerous scattered erect hairs, each arising from a comparatively large puncture; prothorax transverse, with nine tubercles, three on the disk, and three on each side; scutellum brown; elytra very distinctly punctured, the punctures small and rather dispersed, a semicircular obliquely placed mark at the shoulder, and the apex, dark brown; body beneath and legs brown, the basal half of the tibire fulvous; antennæ of the female shorter than the body, the first two joints brown, the third to the sixth fulvous, with brown tips, the remainder dusky. Length 7 lines.

Distinguished from D.obliqua by the shortness of its prothorax and antennæ, and its nearly glabrous and shining surface. $\mathrm{My}_{\mathbf{y}}$ specimen was kindly presented to me by Mr. Du Boulay.

\section{STRONGTLURUS ORBATUS.}

$S$. brunneo-testaceus, subnitidus, pilis albis adpressis dispersis; oculis infra valde approximatis ; prothorace haud maculato, epipleuris metathoracis dense niveo pilosis.

Hab. Queensland.

Brownish testaceous, subnitid, with scattered, white, mostly adpressed hairs; head contracted below the eyes, but gradually broader towards the mandibles; eyes closely approximate beneath; prothorax rather finely punctured, uniformly pilose; scutellum subscutiform, rounded posteriorly, densely covered with white hairs ; elytra strongly punctured at the base, gradually becoming less so posteriorly, each puncture giving rise to a single hair, the apex of each elytron a little rounded at the suture, where it terminates in a strongly marked spine, two or four irregular, brown, and probably uncertain, zigzag spots on 
MR. F. P. PASCOE ON THE LONGICORNIA OF AUSTRALIA. 101

the disk; body beneath and legs thinly clothed with long pale-greyish hairs ; the epipleuræe of the metathorax with a dense white pile; antennæ with the five basal joints covered with loose stiffish hairs, the remainder with a fine uniform pubescence. Length 12 lines.

Allied to S. scutellatus, Hope*, but without any spots on the prothorax, the apex of each elytron strongly spined, the eyes considerably more approximate beneath, the metathoracic epipleuræ covered with a dense white pile, and other characters.

\section{Oxymagis.}

Caput antice paulo productum. Oculi prominuli, anguste emarginati, supra distantes. Antenne breviusculæ, basi remotæ; scapo modice elongato, obconico; articulis tertio et quarto brevioribus, cylindricis; cæteris paulo longioribus et subæqualibus. Palpi breves, articulo ultimo triangulari. Prothorax capite latior, apice angustus, antice utrinque rotundatus, basi bisinuatus, angulis posticis productis. Elytra prothorace multo latiora, oblonga, parallela. Pedes mediocres, antici breviores, postici longiores; femora in medio incrassata ; tarsi subdilatati, fere æquales. Acetabula antica integra. Prosternum latum, elevatum, postice transverse dilatatum. Mesosternum elevatum, antice dilatatum et perpendiculare.

Nearly related to Strongylurus, Hope, but the palpi short, with the terminal joint triangular, and the pro- and mesosterna produced, with broad opposing perpendicular faces. I have dedicated the species described below to Dr. Gray.

\section{Oximagis Grayit.}

$O$. fuscus, sparse griseo pubescens; prothorace lateribus dense albo tomentoso; elytris brumneis; antennis, tibiis tarsisque fulvo-ferrugineis.

$\mathrm{Hab}$.

Dark brown, with scattered greyish adpressed hairs, each issuing from a small puncture in the derm; head with a wide semicircular impression between the eyes; prothorax with a dense pure-white tomentose stripe on eacb side; elytra reddish brown, the apex of each rounded; body beneath thickly pubescent at the sides; antennæ, tibiæ, and tarsi yellowish ferruginous. Length 11 lines.

\section{OPSIDOTA ALBIPILOSA.}

$O$. fusca, supra sparse albo pilosa, infra dense pilosa ; antennis brunneis, subtilissime pubescentibus; tarsis rufescentibus.

Hab. South Australia (Gawler).

* This was the type of my genus Isalium. At the time of proposing it I was under the impression that Strongylurus, Hope, was synonymous with Didymocantha, Newr. ; the former author, however, gives S. scutellatus as the type, not distinguishing it from Didymocantha, but separating Coptopterits. 
Dark brown, covered above with numerous, slightly dispersed, white hairs, one, or sometimes two or three, issuing from a puncture in the derm; body beneath with more closely set hairs nearly concealing the derm; elytra apiculate at the suture; antennæ reddish brown, covered, except the first two joints, with a very delicate pubescence; legs brown, with a greyish pile, the tips of the tibiæ and tarsi reddish. Length 12 lines.

A much finer species than $O$. infecta, more cylindrical, the prothorax more rounded at the sides and without spots, and the tarsi more dilated, if this be not, as in some other cases, a sexual character. I owe my specimen to the kindness of Mr. Odewalin.

\section{Paphora.}

Caput porrectum, ovatum; tuberibus antenniferis brevibus, remotis. Oculi reniformes. Antenna breves, scapo quam articuli tertii et quarti longiore, cæeteris paulo longioribus. Mandibula, palpi \&c. breviuscula. Prothorax ovatus, basi apiceque truncatus, capite paulo latior. Elytra breviuscula, lateribus parallela, apicibus rotundatis. Pedes mediocres; femora vix incrassata; tibie quam tarsi longiores. Proet mesosterna declivia, hoc haud elongatum. Abdominis segmenta sensim breviora.

The type of this genus is my Ceresium? modestum (Journ. Ent. ii. p. 237). The genus, however, is nearer Bebius (op. cit. p. 369); but it has no muzzle, and is altogether a much shorter form, with longer legs. It agrees with it in having the scape longer than either the third or fourth joints-a peculiarity which at present distinguishes these genera from all others of the subfamily belonging to the Australian fauna.

\section{Porithea.}

(ठ) Caput antice breve, transversum. Oculi magni, reniformes. Antenne corpore multo longiores, scapo clavato, articulo tertio longiore, quarto breviore, quinto et sequentibus longioribus. Palpi securiformes. Prothorax basi constrictus. Elytra parallela, apice rotundata. Pedes longiores; femora valida, valde clavata, postica elytrorum extremitatem superantia; tibia subelongatæ; tarsi antici dilatati. Prosternum simplex. Mesosternum declive. (ㅇ) Antenna et pedes breviores; femora minora; tarsi antici haud dilati.

There are three or four unpublished Malayan genera that will come between this genus and Ceresium. The chief characters, however, that will differentiate it from cognate forms lie in the contracted base of the prothorax, the stout clavate (not fusiform) femora, especially of the male (in which sex the posterior pair extend beyond the end of the body), and the short transverse face. The type (Callidium intortum, Newm.) is in Major Parry's col- 
MR. F. P. PASCOE ON THE LONGICORNIA OF AUSTRALIA. 103

lection; but the precise habitat of that and his other specimens, like the one in my own, is unknown.

\section{Aridads heros.}

A. rufo-flavus, nigro fasciatus ; prothorace oblongo-ovato, antice angustato ; elytris apice truncatis, angulo exteriore producto ; antennis muticis.

$H a b$. Port Albany (north coast).

Nearly glabrous, rufous yellow, banded, or otherwise varied with black; head with a deep semicircular impression above the clypeus, labrum sinuato-emarginate; prothorax oblong ovate, narrowed anteriorly, closely punctured, the intervals sharply irregular, behind on each side a broad slightly elevated protuberance, the sides black, clothed with greyish hairs ; scutellum triangular, with a fulvous-grey pilosity; elytra covered with closely-set deeply-impressed punctures, posteriorly several black tubercular points, from the scutellum on each side a black curved stripe extends downwards and outwards as far as the middle, a curved band of rufous yellow follows, the remainder black, apices truncate, the outer angle produced; body beneath and legs black, a fulvous patch on the abdomen, and the anterior femora, except at the base, fulvous ; fore and intermediate tarsi clothed with yellowish hairs ; antennæ black. Length 10 lines.

Besides the difference of colour, which, however, is probably variable, this species differs from $A$. thoracicus in the longer prothorax, so narrowed anteriorly as to give it an ovate form, in the very decided truncation of the elytra, and the antennæ without apical spines in the male.

\section{Hommmota Deboulayi.}

H. rufo-brunnea, parte apicali nigra, nitida; femoribus posticis pone corpus exeuntibus.

Hab. Western Australia (Mr. Du Boulay).

Reddish brown, with long slender dispersed hairs; head finely punctured, a broad groove between the eyes terminating above the mouth in a semilunar impression; prothorax with numerous shallow, almost obsolete punctures, much longer than broad, its base slightly elongated; scutellum parallel at the base, triangular towards the apex; elytra divided in the middle by an oblique ivory line, reddish brown, and thickly punctured anteriorly to this line, behind the line nearly impunctate, glossy, gradually acquiring a whitish pubescence towards the apex; body beneath black; the breast reddish brown; legs reddish brown; the femora robust, the posterior extending beyond the elytra; antennæ longer than the body, reddish brown. Length 4 lines.

This species is closely allied to $H$. basalis, but differs in colour, in the less punctured prothorax, which is much more elongated 
at the basal constricted portion, differently shaped scutellum, longer legs, and considerably stouter femora.

\section{Ectosticta.}

Antenne corpore breviores, scapo articulo tertio fere zquali, sequentibus brevioribus et subæqualibus. Oculi subtenuiter granulati. Prothorax basi haud attenuatus. Acetabula antica fere integra. Cæteris ut in Ipomoria.

The type of this genus is the Callidium cleroides, White. It is a stouter form than Homamota, with which it agrees in its nearly entire anterior acetabula; but differs in the shorter antennw, the altered proportions of their basal joints, and the rounded prothorax not attenuated at the base. The following is a new species.

\section{Ectosticta RUIDA.}

$E$. fusca, nitida ; capite prothoraceque rufis, hoc grosse punctato; scapo nitido, disperse punctato; elytris omnino confertim punctatis, flavo bifasciatis.

Hab. Champion Bay (West Australia).

Slightly pilose, dark brown, shining; head reddish, closely punctured: antennæ reddish, apices of most of the joints dark brown, the scape shining, sparingly punctured; prothorax reddish, with much larger punctures than in $E$. cleroides; scutellum subquadrate; elytra entirely punctured, but the punctures larger and less crowded posteriorly, the base reddish, between the base and middle a transverse yellowish line, interrupted at the suture, directly behind the middle a somewhat $V$-shaped line; body beneath shining, the last four abdominal segments and legs dark brown, the bases of the femora and sterna reddish. Length 4 lines.

\section{IPOMORIA.}

Caput insertum, triangulare, antice paulo productum, tuberibus antenniferis obsoletis. Oculi mediocres, reniformes, tenuiter granulati. Antenne corpore breviores, basi distantes, scapo obconico; articulo tertio breviore, apice mutico; cæteris longioribus, apicibus incrassatis. Mandibula parve. Prothorax ad latera rotundatus, basi attenuatus. Elytra brevia, parallela. Coxce anticæ globosæ, subcontigux. Acetabula antica subanguste angulata. Femora abrupte clavata ; tarsi breviusculi. Pro- et mesosterna declivia. Corpus depressum.

Mr. Newman's genus Monoplia appears to be very nearly allied to this, and to be distinguished principally by the third joint of the antennæ being spined, as in Apilocera, Cyrtophorus, \&c. Ipomoria is also allied to Homomota and Ectosticta, but is differentiated from both by the shortness of the third joint of the antennæ, which is shorter than the scape. 


\section{IPOMORIA THLLIDES.}

I. fusca, subnitida; prothorace longitudinaliter plicato; elytris fasciis duabus interruptis flavescentibus.

$H a b$. South Australia.

Dark brown, slightly nitid; head closely punctured; prothorax broader than the head, marked longitudinally with a number of short raised lines, the middle with two large shallow depressions; scutellum subquadrate, slightly bilobed at the apex; elytra not broader than the prothorax, rugosely punctured, but the punctures fewer posteriorly ; each elytron with two yellowish bands, the first before the middle, widely interrupted at the suture, the second behind the middle, nearly approaching the suture; body beneath and femora glossy brown, anterior femora rather compressed; antennæ a little more than half the length of the body, pitchy, with a few long scattered hairs. Length 3 lines.

\section{AdRIUM.}

Oculi grosse granulati. Antenna corpore breviores vel elytrorum medium vix superantes, articulo tertio quam scapus breviore, illo quarto xquali, sequentibus longioribus. Prothorax postice constrictus, disco impresso. Acetabula antica fere integra. Cæteris ut in Ipomoria.

Callidium catoxanthum, White, is the type of this genus, which, like Ipomoria and Eotosticta, has more the habit of a Callidium than of a Clytus; nevertheless the coarsely granulated eyes and nearly entire anterior acetabula are at variance with the two most important characters of the Callidiina.

\section{OEbarina.}

Caput antice breve, tuberibus antenniferis obsoletis. Oculi magni, anguste emarginati, grosse granulati. Antenne corpori vix æquales, vel breviores, graciles, basi modice distantes, scapo brevi, obconico, articulo quarto quam tertius breviore, cæeteris longioribus et aqualibus vel fere æqualibus. Palpi, præsertim maxillares, elongati, articulo ultimo triangulari. Prothorax oblongus, lateribus subparallelis vel leviter rotundatis. Elytra elongata, parallela. Pedes modice elongati; $f e-$ mora fusiformia ; tibia sublineares ; tarsi graciles, posticæ fere lineares. Coxce anticæ globosæ. Acetabula antica integra. Prosternum angustum, postice acutum. Mesosternum latum, declive. Corpus depressum.

Differs from Phacodes, Newm., in the elongate palpi terminating in a broadly triangular joint, and in the slender and nearly linear tarsi.

\section{CEbarista tristis.}

E. fusca, nitida, sparse albo hirta ; prothorace lateribus subparallelis. Hab. South Australia (Mr. Odewahn). 
Dark brown, shining, with scattered stiff whitish hairs; head and prothorax equal in breadth, covered with close confluent punctures; the latter oblong, narrower posteriorly, with its sides somewhat parallel; scutellum whitish from numerous close-set and decumbent hairs; elytra a little broader than the prothorax, thickly but not confluently punctured, the sides perfectly parallel, the apex rounded; body beneath and legs chestnut-brown, shining, with sparse decumbent hairs; antennæ brownish testaceous, rather shorter than the body. Irength 5 lines.

\section{CEBARINA CERESIOIDES.}

$\boldsymbol{E}$. fusca, nitida, sparse albo hirta; prothorace lateribus rotundatis.

Hab. South Australia (Mr. Odewahn).

Dark brown, shining, with scattered stiff whitish hairs; head narrower than the prothorax; the latter rounded at the sides, and scarcely longer than broad, both coarsely and confluently punctured; scutellum triangular, hairy, white; elytra closely and more coarsely punctured than in $\boldsymbol{E}$. tristis, and slightly incurved behind the shoulders; body beneath and legs as in $\boldsymbol{E}$. tristis, but the postpectus reddish testaceous; antennæ pale ferruginous, much shorter than the body. Length 7 lines.

\section{LAMIID正. \\ ACANTHODERINA. HeBESECTs.}

Hebesecis, Pascoe, Journ. of Entom. ii. p. 353.

Hebecerus, J. Thomson, Essai, etc. p. 342 (non Kolenati).

Hebesecis MARgINICOLlis. (Acanthocinus marginicollis, Boisduval, Voy. de l'Astrol. ï. p. 490, pl. 9. f. 12.)

$H a b$. South Australia; Victoria; New South Wales; Queensland; Tasmania.

H. linfola. (Acanthocinus lineola, Newman, Zool. 1855, App. exxx.

Qu. var. Hebecerus marginicollis, Bois.?)

$H a b$. Victoria; Kangaroo Island; Tasmania.

H. Austra lis. (Acanthocinus Australis, Boisduval, Voy. de l'Astrol. ii. p. 489. Hebecerus inglorius, Newman, Entom. p. 361.)

Hab. Victoria; New South Wales; South Australia.

H. Crocogaster, Boisduval, Voy. de Astrol. ii. p. 492.

Hab. South Australia; Victoria; New South Wales; Western Australia.

H. conferta, Pascoe, Trans, Ent. Soc. ser. 3. i. p. 528.

Hab. Queensland.

H. NIPHONoIdes, Pascoe, ib. p. 527.

Hab. Port Curtis, Western Australia.

H. spársa, Pascoe, antè, p. 81.

Hab. Western Australia. 
Mr. F. P. PASCOE ON THE LONGICORNIA OF AUSTRALIA. 107

? H. Fusciconnis. (Acanthoderes fuscicornis, Germar, Linn. Ent. iii. p. 227.)

Hab. South Australia.

H. variconnis. (Crossotus varicornis, Germar, Linn. Ent. iii. p. 229. ? H. marginicollis, Bois.)

Hab. South Australia; New South Wales.

H. Germari, Pascoe, Journ. of Entom. ii. p. 352.

Hab. South Australia.

H. Sordida, Pascoe, Trans. Ent. Soc. ser. 3. i. p. 527. (Velora Australis, Thomson, Syst. Ceramb. p. 56.)

$H a b$. Clarence River.

H. antennata, Pascoe, Journ. of Entom. ii. p. 353.

Hab. Port Denison.

\section{Probatodes.}

Probatodes, J. Thomson. Syst. Ceramb. p. 56.

Probatodes plumula. (Acanthocinus? plumula, Newm. Zool. 1855, App. cxxx.)

$H a b$. Tasmania ; Victoria.

AMerpsis.

Ameipsis, Pascoe, Journ. of Entom. ii. p. 354.

Ameipsis marginicollis, Pascoe, $i b$. p. 354.

$H a b$. Queensland.

Prosoplus.

Prosoplus, Blanchard, Voy. au Pôle Sud, iv. p. 290.

Prosoplus Hollandicus. (Acanthocinus Hollandicus, Boisd. Voy. de l'Astrol. ii. p. 491.)

Hab.

\section{EXOCENTRINÆ.}

\section{Pentacosmia.}

Pentacosmia, Newman, Entom. p. 361.

Pentacosmia scoparia, Newm. Ent. p. 361 .

Hab. Victoria ; Queensland.

NeIssa.

Neissa, Pascoe, antè, p. 82.

Neissa inconspicua, Pascoe, antè, p. 82, tab. 3. fig. 4.

$H a b$. Gawler.

N. Nigrina, Pascoe, antè, p. 82.

Hab. Gawler.

ItLANA.

Illæna, Erichson, Wiegmann's Arch. 1842, p. 225. 
ILLANA EXILIS, Erichson, ib. p. 225.

Hab. Tasmania.

\section{MESOSIN里.}

\section{BUCYNTHIA.}

Bucynthia, Pascoe, ante, p. 83.

Bucynthia spiloptera. (Hygocera spiloptera, Pascoe, Trans. Ent. Soc. ser. 3. i. p. 542.)

Hab. Hunter's River.

\section{NIPHONIN AR.}

\section{Atgomomos.}

Egomomus, Pascoe, Long. Malay. p. 59.

Micracantha, Montrouzier (nom. præoc.?), Ann. de la Soc. Ent. de France, ser. 4. i. p. 271.

Agomom us Woodlarkianus. (Penthea Woodlarkiana, Montrouzier, Faune de Woodlark, p. 65 . Niphona Bakewelli, Pascoe, Trans. Ent.

Soc. ser. 2. v. p. 38 . Praonetha pörosa, Faldermann.)

Hab. Queensland.

E. Torosus. (Niphona torosa, Pascoe, Journ. of Entom. ii. p. 223.)

Hab. South Australia.

A. misellus, Pascoe, Trans. Ent. Soc. ser. 3. i. p. 529.

Hab. Port Curtis.

A. oblitus, Pascoe, ib. p. 530.

Hab. New South Wales.

E. Iratus, Pascoe, Ann. \& Mag. Nat. Hist. ser. 3. ix. p. 464.

Hab. Lizard Island.

A. Insularis, Pascoe, Trans. Ent. Soc. ser. 2. v. p. 39 (1857).

Coptops abdominalis, White, Ann.\& Mag. Nat. Hist. 3 ser.ii.p. 273(1858).

Hab. Port Essington.

\section{Conrhenes.}

Corrhenes, Pascoe, Journ. of Entom. ii. p. 355.

Saperda, Germar, Linn. Ent. iii. p. 230.

Corrhenes paula. (Saperda paula, Germar, ib. p. 230.)

Hab. New South Wales; South Australia; Victoria.

C. Funesta. (Saperda funesta, Pascoe, Trans. Ent. Soc. ser. 2. v. p. 53.)

Hab. South Australia.

C. strgmatica. (Saperda stigmatica, Pascoe, ib. ser. 3. i. p. 544.)

Hab. Port Curtis.

C. mystica. (Saperda mystica, Pascoe, ib. p. 545.)

Hab. New South Wales?

C. guttata, Pascoe, Journ. of Entom. ii. p. 355.

Hab. New South Wales. 
MR. F. P. PASCOE ON THE LONGTCORNIA OF AUSTRALIA. 109

\section{Srsspmotos.}

Sysspilotus, Pascoe, ib. p. 359.

Sysspilotus Macleayi, Pascoe, ib. p. 360 .

Hab. Rockhampton.

\section{SYMPHYLETES.}

Symphyletes, Newman, Entom. p. 362.

Symphy LETES Nodosus, Newman, ib. p. 362. (Lamia pulverulens,

Boisduval, Voy. de l'Astrol. ii. p. 501. L. subfasciata, Hope.)

Hab. Victoria; New South Wales; Queensland.

S. rumatus, Pascoe, Journ. of Entom. ii. p. 224.

Hab. South Australia.

S. Anctos, Pascoe, ib. p. 356.

Hab. Western Australia; South Australia.

S. PEDICoRnIs. (Lamia pedicornis, Fabricius, Syst. Ent.p.170. Cerambyx pedicornis, Olivier, Ent. no. lxvii. pl. 16. f. 119, p. 94.)

Hab. New South Wales; Port Curtis.

S. ingestus, Pascoe, Trans. Ent. Soc. ser. 3. i. p. 537.

Hab. New South Wales.

S. vetustus, Pascoe, Ann. \& Mag. Nat. Hist. ser. 3. ix. p. 264.

Hab. Lizard Island.

S. moratus, Pascoe, Trans. Ent. Soc. ser. 3. i. p. 536.

Hab. Port Curtis.

S. Devotus, Pascoe, antè, p. 83.

Hab. Western Australia.

S. solutus, Pascoe, Trans. Ent. Soc. ser. 3. i. p. 535.

Hab. Port Curtis.

S. munitus, Pascoe, ib. p. 536.

Hab. Clarence River.

S. Neglectus, Pascoe, ib. p. 534.

Hab. New Sonth Wales.

S. Sodalis, Pascoe, ib. ser. 2. iv. p. 41.

Hab. Queensland.

S. farinosus, Pascoe, ib. ser. 3. i. p. 533.

Hab. Port Curtis.

S. ANGasir, Pascoe, Journ. of Entom. ii. p. 225, pl. 11. f. 1.

Hab. South Australia; Western Australia.

S. pubiventris, Pascoe, ib. i. p. 339.

Hab. South Australia. 
S. Duboulayi, Pascoe, antè, p. 83.

Hab. Western Australia.

S. MAculicornis, Pascoe, Trans. Ent. Soc. ser. 2. iv. p. 250. Hab. Western Australia.

S. subtuberculatus, White, Ann.\&Mag. Nat. Hist. ser. 3. ii. p. 269. Hab. - ?

S. Fulvescens, Pascoe, Trans. Ent. Soc. ser. 3. i. p. 531. Hab. Port Curtis.

S. subminiatus, Pascoe, antè, p. 84.

Hab. Western Australia.

S. Cinnamomeus, Pascoe, Trans. Ent. Soc. ser. 2. v. p. 59.

Hab. Queensland.

S. Lateralis, Pascoe, ib. ser. 2. iv. p. 250.

Hab. Western Australia; South Australia.

S. colla RIs. (Saperda collaris, Donovan, Epit. Ins, N. Holl. \&c. pl. Hab. —?

S. Decipiens, Pascoe, Trans. Ent. Soc. ser. 3. i. p. 532.

Hab. South Australia.

S. Nigro-virens, Donovan, Ins. of New Holland, pl.

$H a b$. New South Wales; Queensland.

S. Derasus, Pascoe, Trans. Ent. Soc. ser. 3. i. p. 532.

Hab. New South Wales.

S. Egenus, Pascoe, Journ. of Entom. ii. p. 225.

Hab. North Australia.

S. Satelles, Pascoe, $i b$. p. 357 .

$H a b$. Western Australia.

S. simrus, Pascoe, antè, p. 85.

Hab. Champion Bay (Western Australia).

S. Bathurstir, Pascoe, antè, p. 85.

Hab. South Australia (Gawler).

S. variolosus, Pascoe, Journ. of Entom. i. p. 340.

$H a b$. New South Wales; Queensland; South Australia.

S. Iliacus, Pascoe, antè p. 84.

Hab. Champion Bay (Western Australia).

S. vicarius, Pascoe, Journ. of Entom. ii. p. 356.

$H a b$. New South Wales? Queensland.

S. humeralis, White, Ann. \& Mag. Nat. Hist. ser. 3. ii. p. 269.

Hab. North Australia (Port Essington).

S. Gallus, Pascoe, Journ. of Entom. ii. p. 226.

Hab. North Australia (Stewart's Expedition). 
Mr. F. P. Pasgoe on the longtcornia of australia. 111

S. Albo-cinctus. (Saperda albo-cincta, Guérin, Voy. de la Coq. t. ii. p. 137, pl. 7. f. 7. Rhytiphora Donovani, Newman, Zool. 1851, App. exxix. ?S. collaris, Donovan.)

Hab. New South Wales; Queensland.

S. vestigialis, Pascoe, Journ. of Entom. ii. p. 226.

Hab. South Australia.

S. Solandri. (Lamia Solandri, Fabricius, Syst. Ent. p. 177. Cerambyx Solandri, Olivier, Entom. no. Ixvii. pl. 16. f. 118, p. 100.)

$H a b$. New South Wales.

\section{Ipiliastus.}

Iphiastus, Pascoe, Journ. of Entom. ii. p. 357.

Iphiastus heros. (Symphyletes heros, Pascoe, Trans. Ent. Soc. ser. 3. i. p. 531; Journ. of Entom. ii. pl. 16. f. 4.)

Hab. (Interior?) Australia (Stewart's Expedition).

\section{Platymopsis.}

Platymopsis, J. Thomson, Arch. Entom. i. p. 187.

Platymopsis obliqua. (Lamia obliqua, Donovan, Ins. New Holl.pl.)

Hab. Queensland; New South Wales; South Australia.

P. Tuberculata. (Rhytiphora tuberculata, Hope, Ann. \& Mag. Nat. Hist. 1842, ix. p. 429.)

Hab. Port Essington.

P. A Rmatula. (Sympheletes (Platymopsis) armatulus, White, Proc. Zool. Soc. 1859, p. 122, pl. 59.f. 8.)

Hab. (South ?) Australia.

\section{RHYTIPHORA.}

Rhytiphora, Serville, Ann. Soc. Ent. de France, iv. p. 37.

RHYTIPHORA RUGicollis. (Lamia porphyrea, Donovan. L. rugicollis, Dalman, Schön. Syn. Ins. iii. App. 169.)

Hab. New South Wales; Queensland.

R. Amicula, White, Proc. Zool. Soc. 1859, p. 122, pl. 59. f. 7.)

Hab. Victoria River.

R. Polymita, Pascoe, Trans. Ent. Soc. ser. 2. v. p. 60.

Hab. Queensland.

R. Wateruouset, Pascoe, Journ. of Entom. ii. p. 228.

Hab. South Australia.

R. piperitia, Hope, Ann. \& Mag. Nat. Hist. 1842, ix. p. 429.

Hab. Port Essington.

R. Detrita, Hope, Ann. \& Mag. Nat. Hist. 1842, ix. p. 429.

$\mathrm{Hab}$. Port Essington. 
112 Mr. F. P. PASCOE ON THE hoNGrCoRNta OF AUstralta.

R. Sospita lis, Pascoe, Journ. of Entom. ii. p. 358.

Hab. Western Australia.

R. CAPRINA, Newman, Entom. p. 362.

Hab. South Australia; Victoria.

R. Mista, Newman, ib. p. 362 .

Hab. Victoria.

R. sAGA, Pascoe, Journ. of Entom. ii. p. 358.

Hab. Western Australia.

R. squivistita, Pascoe, antè, p. 86.

Hab. Western Australia (Perth).

R. RUbeta, Pascoe, Trans. Ent. Soc. ser. 3. i. p. 538.

Hab. New South Wales.

R. critata, Pascoe, ib. ser. 2. v. p. 60.

Hab. Queensland.

\section{Penthea.}

Penthea, Laporte, Hist. Nat. des An. Art. ii. p. 476.

Penthea vermicularia. (Lamia vermicularia, Donovan, Ins. New Holl.)

Hab. New South Wales; Queensland.

P. solidd, Pascoe, Trans. Ent. Soc. ser. 3. i. p. 538.

Hab. Clarence River.

P. costata, Pascoe, ib. p. 539.

Hab. New South Wales; Western Australia.

P. Saundersil, Pascoe, ib. ser. 2. iv. p. 103.

Hab. Western Australia.

P. pullina, Pascoe, it, ser. 3. i. p. 539.

Hab. Western Australia.

P. sannio. (Lamia sannio, Newman, Entom. Mag. v. p. 498.)

Hab. —?

P. pardaris. (Lamia pardalis, Newman, Entom. p. 414.)

Hab. New South Wales; Queensland.

P. Miliaris, Pascoe, Trans. Ent. Soc. ser. 3. i. p. 540.

Hab. Port Curtis.

P. Intricata, Pascoe, Journ. of Entom. ii. p. 227.

Hab. South Australia.

P. scenica, Pascoe, Trans. Ent. Soc. ser. 3. i. p. 540.

Hab. Port Curtis.

P. CRassicollis, Pascoe, Journ. of Ent. ii. p. 227.

Hab. Interior of Australia (Stewart's Expedition).

P. PICta, Pascoe, ib. p. 227, pl. 11. f. 5.

Hab. South Australia. 